Article

\title{
New Neolignans and a Phenylpropanoid Glycoside from Twigs of Miliusa mollis
}

\author{
Kanokporn Sawasdee ${ }^{1}$, Tanawat Chaowasku ${ }^{2}$ and Kittisak Likhitwitayawuid ${ }^{1, *}$ \\ 1 Department of Pharmacognosy, Faculty of Pharmaceutical Sciences, Chulalongkorn University, \\ Bangkok 10330, Thailand; E-Mail: skanokporn7@hotmail.com \\ 2 Nationaal Herbarium Nederland, Leiden University, The Netherlands; \\ E-Mail: chaowasku@nhn.leidenuniv.nl \\ * Author to whom correspondence should be addressed; E-Mail: Kittisak.L@chula.ac.th; \\ Tel.: +66-221-88-360 Fax: +66-221-88-357.
}

Received: 8 December 2009; in revised form: 20 January 2010 / Accepted: 22 January 2010 / Published: 28 January 2010

\begin{abstract}
From the twigs of Miliusa mollis Pierre, three new compounds including (2S,3S)-2,3-dihydro-2-(4-methoxyphenyl)-3-methyl-5-[1(E)-propenyl]benzofuran, $(7 S, 8 S)$ threo- $\Delta^{8^{\prime}}-4$-methoxyneolignan and tyrosol-1- $O-\beta$-xylopyranosyl-( $\left.1 \rightarrow 6\right)-O-\beta$-glucopyranoside were isolated, along with seven known compounds. Their structures were elucidated through analysis of their spectroscopic data.
\end{abstract}

Keywords: neolignan; phenylpropanoid glycoside; Miliusa mollis

\section{Introduction}

The genus Miliusa Lesch. ex A.DC. (Annonaceae) comprises 30-40 species, which occur from India and South China to North Australia [1]. So far, there have been only a few reports on the constituents of plants in this genus, describing the presence of aporphine alkaloids, terpenoids, flavonoids, phenylpropanoids, styrylpyrones, bis-styryls and homogentistic acid derivatives [2-12]. Miliusa mollis Pierre, is a shrub found in the northern and central regions of Thailand where it is locally known as Ching-chap [13]. Prior to this investigation, no studies had been done to examine the chemical components of this plant. The current paper describes the isolation and structural elucidation of three new compounds from the twigs of M. mollis. 


\section{Results and Discussion}

In this study, we report the isolation of two new neolignans including (2S,3S)-2,3-dihydro-2-(4methoxyphenyl)-3-methyl-5-[1(E)-propenyl] benzofuran (1) and (7S,8S)- threo- $\Delta^{8^{\prime}-4-}$ methoxyneolignan (3), and a new glycosidic phenylpropanoid, namely tyrosol-1- $O-\beta$-xylopyranosyl$(1 \rightarrow 6)-O-\beta$-glucopyranoside $(\mathbf{1 0})$, together with seven known compounds: $(2 R, 3 R)-2,3$-dihydro-2-(4hydroxy-3-methoxyphenyl)-3-methyl-5-(E)-propenylbenzofuran (2) [14], conocarpan (4) [14-16], (-)epicatechin (5) [17-18], liriodenine (6) [19-20], asimilobine (7) [21-22], (-)-norushinsunine (8) [23] and icariside $\mathrm{D}_{2}(\mathbf{9})$ [24] (Figure 1). The structures of these known compounds were identified by comparison of their spectral data with those reported in the literature.

Figure1. Compounds isolated from Miliusa mollis.
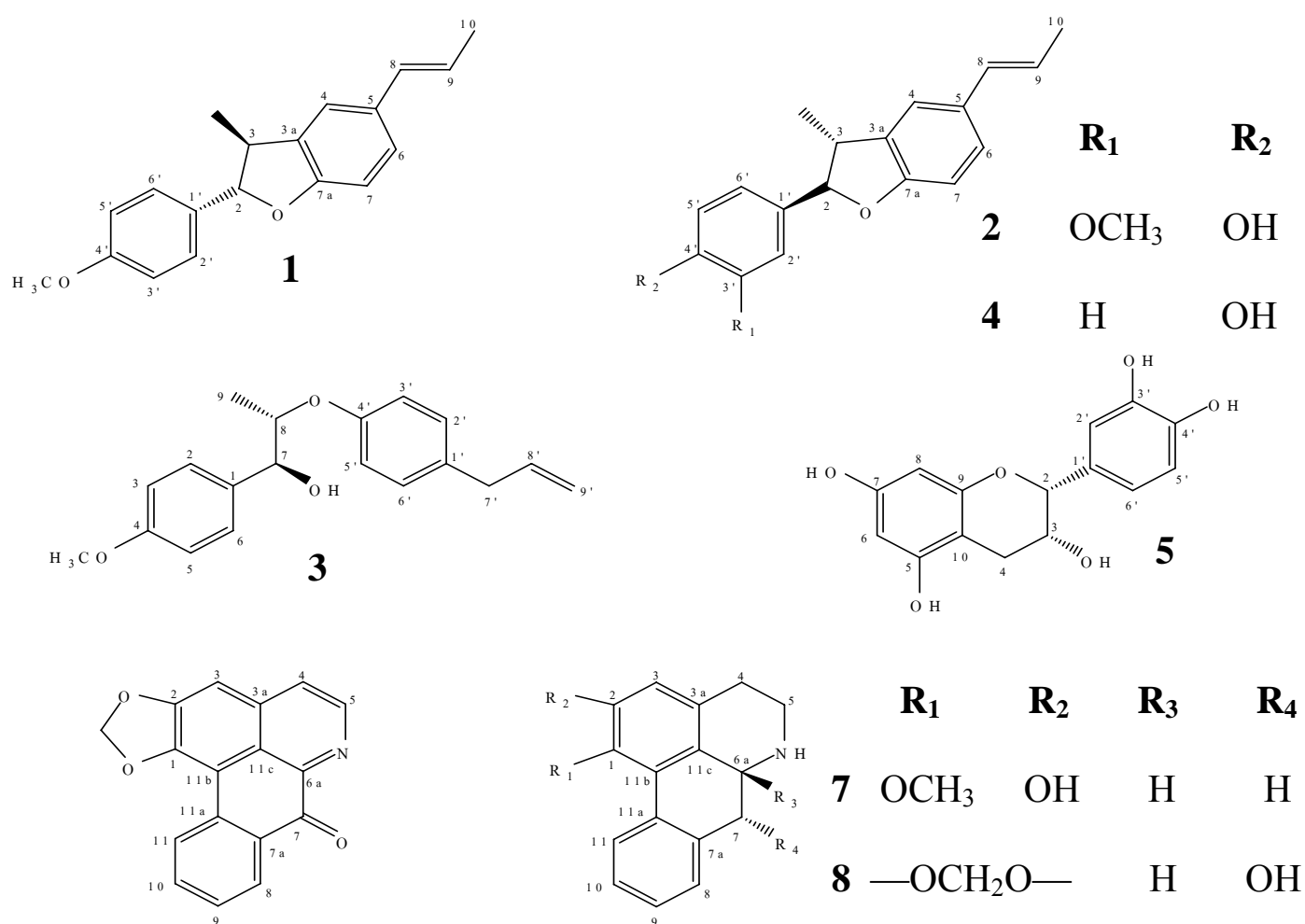

6
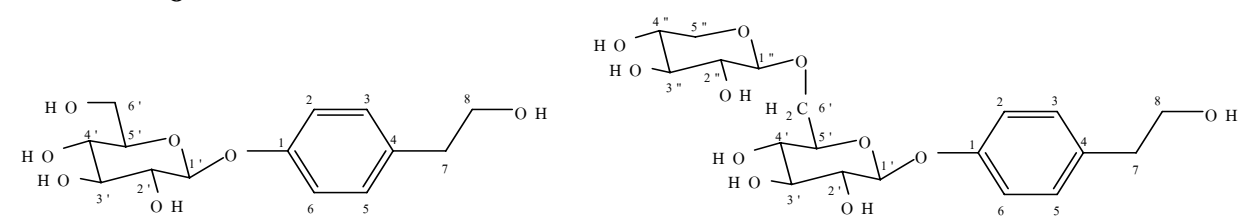

9

10

Compound 1 was obtained as a colorless oil. The positive HRESITOFMS exhibited an $[\mathrm{M}+\mathrm{Na}]^{+}$ion at $m / z$ 303.1280, suggesting the molecular formula $\mathrm{C}_{19} \mathrm{H}_{20} \mathrm{O}_{2}$. The $\mathrm{UV}$ spectrum showed two absorption maxima at 228 and $274 \mathrm{~nm}$, and the IR spectrum exhibited absorption bands for conjugated unsaturation $\left(1,515\right.$ and $\left.1,486 \mathrm{~cm}^{-1}\right)$, and ether $\left(1,243 \mathrm{~cm}^{-1}\right)$ functionalities. The ${ }^{1} \mathrm{H}-\mathrm{NMR}$ signals at $\delta 5.09(1 \mathrm{H}, \mathrm{d}, J=9.0 \mathrm{~Hz}, \mathrm{H}-2), 3.39(1 \mathrm{H}, \mathrm{m}, \mathrm{H}-3)$ and $1.39(3 \mathrm{H}, \mathrm{d}, J=6.6 \mathrm{~Hz}, \mathrm{Me}-3)$ and the ${ }^{13} \mathrm{C}-\mathrm{NMR}$ resonances at $\delta 92.6,45.2$, and 17.8 are characteristic features of the trans-2-aryl-3-methyl- 
2,3-dihydrobenzofuran system [14]. This was supported by the NOESY interactions of Me-3 protons with $\mathrm{H}-2$. In the structure of $\mathbf{1}$, a methoxy group [ $\delta_{\mathrm{H}} 3.81(3 \mathrm{H}, \mathrm{s}) ; \delta_{\mathrm{C}} 55.3$ ] was present at $\mathrm{C}-4^{\prime}$, as indicated from the HMBC correlations from the protons at $\delta 3.81$ to $\mathrm{C}-4^{\prime}(\delta 158.3)$, and from $\mathrm{H}-2^{\prime}\left(6^{\prime}\right)$ $(\delta 7.35,2 \mathrm{H}, \mathrm{d}, J=8.7 \mathrm{~Hz})$ to $\mathrm{C}-2(\delta 92.6)$ and $\mathrm{C}-4{ }^{\prime}$. In addition, a 2-propenyl moiety $\left[\delta_{\mathrm{H}} 6.37(1 \mathrm{H}, \mathrm{d}\right.$, $J=15.8 \mathrm{~Hz}, \mathrm{H}-8), 6.09(1 \mathrm{H}, \mathrm{dq}, J=15.8,6.3 \mathrm{~Hz}, \mathrm{H}-9), 1.86(3 \mathrm{H}, \mathrm{d}, J=6.3 \mathrm{~Hz}, \mathrm{Me}-10) ; \delta_{\mathrm{C}} 130.8(\mathrm{C}-$ 8), 122.9 (C-9), 18.3 (C-10)] was located at C-5 ( $\delta$ 131.2), as evidenced by the ${ }^{3} J$-coupling from C-5 to H-9 ( $\delta 6.09)$. These spectral data appeared to be superimposable on those reported for synthetic $( \pm)$ trans-2,3-dihydro-2-(4-methoxyphenyl)-3-methyl-5-(1(E)-propenyl)benzofuran [25]. It is known that a trans-2-aryl-3-methyl-2,3-dihydrobenzofuran structure with $2 R, 3 R$ configuration shows a positive Cotton effect at about $260 \mathrm{~nm}$ in the CD spectrum, whereas the reverse is true for the $2 S, 3 S$-isomer [14]. Since 1 showed a negative optical rotation $\left([\alpha]_{D}^{20}-13.22\right)$ and its CD curve exhibited a negative Cotton effect at $264 \mathrm{~nm}$, the structure of $\mathbf{1}$ was determined as (2S,3S)-2,3-dihydro-2-(4methoxyphenyl)-3-methyl-5-[1(E)-propenyl]benzofuran (Figure 1). Figure 2 shows the CD curve of $\mathbf{1}$, in contrast with that of $\mathbf{4}$, which is in the $2 R, 3 R$ series. It should be noted that although the antipodal isomer of 1 was earlier mentioned [26-27], its spectroscopic data were not provided.

Figure 2. CD data of compounds 1 and 4.

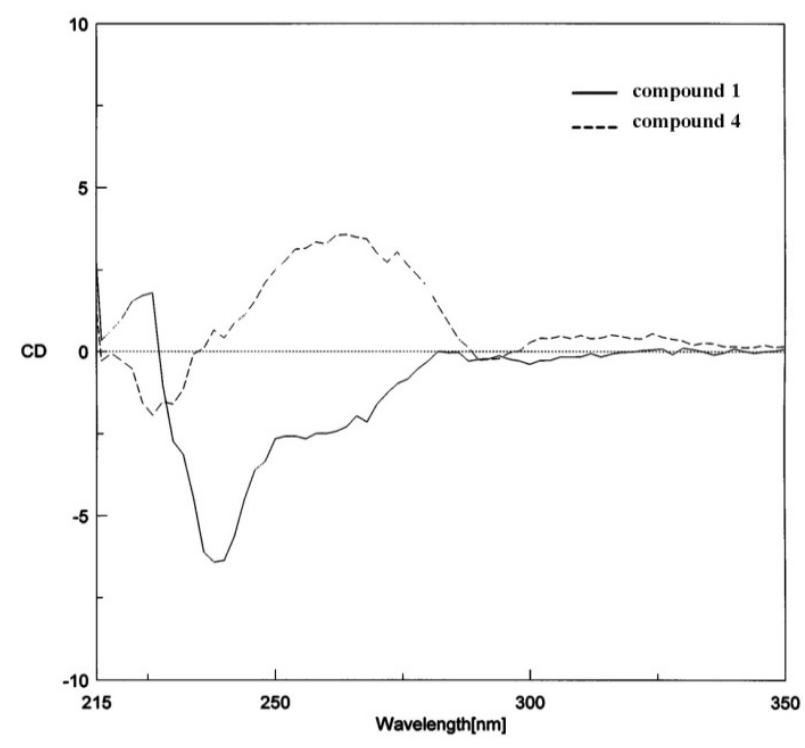

Compound 3 gave an $[\mathrm{M}+\mathrm{Na}]^{+}$ion at $\mathrm{m} / \mathrm{z} 321.1375$ in the HRESITOFMS, indicating a molecular formula of $\mathrm{C}_{19} \mathrm{H}_{22} \mathrm{O}_{3}$. The UV spectrum showed absorption maxima at 227 and $275 \mathrm{~nm}$, and the IR spectrum demonstrated absorption bands for hydroxyl $\left(3,448 \mathrm{~cm}^{-1}\right)$, conjugated unsaturation $\left(1,509 \mathrm{~cm}^{-1}\right)$, and ether $\left(1,243 \mathrm{~cm}^{-1}\right)$ functionalities. The ${ }^{13} \mathrm{C}$-NMR spectrum of 3 (Table 1) showed a nineteen-carbon structure with two $p$-disubstituted benzene rings. In support of this, two pairs of doublets appeared at $\delta 7.32(2 \mathrm{H}, \mathrm{d}, J=8.6 \mathrm{~Hz}, \mathrm{H}-2$ and $\mathrm{H}-6)$ and $6.88(2 \mathrm{H}, \mathrm{d}, J=8.6 \mathrm{~Hz}, \mathrm{H}-3$ and $\mathrm{H}-5)$, and at $\delta 7.09\left(2 \mathrm{H}, \mathrm{d}, J=8.4 \mathrm{~Hz}, \mathrm{H}-2^{\prime}\right.$ and $\left.\mathrm{H}-6^{\prime}\right)$ and $6.87\left(2 \mathrm{H}, \mathrm{d}, J=8.4 \mathrm{~Hz}, \mathrm{H}-3^{\prime}\right.$ and $\left.\mathrm{H}-5^{\prime}\right)$ in the ${ }^{1} \mathrm{H}-\mathrm{NMR}$ spectrum. In the HMQC spectrum, two tertiary oxygenated carbon signals appearing at $\delta$ $77.7(\mathrm{C}-7)$ and $79.3(\mathrm{C}-8)$ showed direct coupling with protons at $\delta 4.62(1 \mathrm{H}, \mathrm{d}, J=7.7 \mathrm{~Hz}, \mathrm{H}-7)$ and $4.34(1 \mathrm{H}, \mathrm{dq}, J=7.7,6.2 \mathrm{~Hz}, \mathrm{H}-8)$, respectively. These two methine protons constituted an ABX coupling system with the Me protons at $\delta 1.07(3 \mathrm{H}, \mathrm{d}, J=6.2 \mathrm{~Hz}, \mathrm{Me}-9)$ in the COSY spectrum. 
Moreover, H-2 and H-6 exhibited 3-bond coupling with C-7, whereas H-8 showed HMBC connectivity to C-4' through an ether linkage (Table 1). These spectral data of $\mathbf{3}$ were similar to those of previously reported 8-O-4'neolignans [28]. Compound 3 should have a methoxy group $\left(\delta_{\mathrm{H}} 3.79,3 \mathrm{H}\right.$, $\left.\mathrm{s} ; \delta_{\mathrm{C}} 55.3\right)$ at C-4 and an allyl moiety $\left[\left(\delta_{\mathrm{H}} 3.32(2 \mathrm{H}, \mathrm{br} \mathrm{d}, J=6.6 \mathrm{~Hz}), 5.05(2 \mathrm{H}, \mathrm{dd}, J=10.2,16.8 \mathrm{~Hz})\right.\right.$ and $5.93(1 \mathrm{H}, \mathrm{m}) ; \delta_{\mathrm{C}} 39.3,115.5$ and 137.7$)$ at $\mathrm{C}-1^{\prime}$. The placement of the $\mathrm{MeO}$ group at $\mathrm{C}-4$ was supported by the HMBC correlation from the MeO-4 protons $(\delta 3.79)$ to $\mathrm{C}-4$ (159.6), which in turn showed ${ }^{3} J$-coupling with H-2 and H-6. In accordance with this proposed structure, HMBC correlations were observed from $\mathrm{C}-1^{\prime}$ to $\mathrm{H}-3^{\prime}\left(5^{\prime}\right)$ and $\mathrm{H}-7^{\prime}$. It is known that for neolignans of this skeleton, the large coupling constant $(J=7.7 \mathrm{~Hz})$ for $\mathrm{H}-7$ and $\mathrm{H}-8$, which was due to the intramolecular hydrogen bonding of the benzylic hydroxyl and the aryloxyl group, suggested a threo relative configuration [29-30]. On the basis of the negative and positive peaks at 276 and $233 \mathrm{~nm}$, respectively in the CD spectrum (Figure 3), the absolute configurations at C-7 and C-8 of 3 were both assigned to be $S$ [30]. Based on the above evidence, the structure of 3 was determined to be $(7 S, 8 S)-$ threo- $\Delta^{8^{\prime}}-4$ methoxyneolignan.

Table 1. ${ }^{1} \mathrm{H}-(300 \mathrm{MHz})$ and ${ }^{13} \mathrm{C}-\mathrm{NMR}(75 \mathrm{MHz})$ data of $3\left(\mathrm{CDCl}_{3}, \delta\right.$ in ppm and $J$ in $\left.\mathrm{Hz}\right)$ and $\mathrm{HMBC}$ correlations.

\begin{tabular}{|l|l|l|l|}
\hline Position & \multicolumn{1}{|c|}{${ }^{\mathbf{H}}$} & ${ }^{13} \mathbf{C}$ & HMBC (correlation with $\left.{ }^{\mathbf{H}} \mathbf{H}\right)$ \\
\hline 1 & - & $132.0(\mathrm{~s})$ & 3,5 and 7 \\
\hline 2 & $7.32(1 \mathrm{H}, \mathrm{d}, 8.6)$ & $128.5(\mathrm{~d})$ & 6 and 7 \\
\hline 3 & $6.88(1 \mathrm{H}, \mathrm{d}, 8.6)$ & $113.9(\mathrm{~d})$ & 5 \\
\hline 4 & - & $159.6(\mathrm{~s})$ & 2,6 and $\mathrm{MeO}$ \\
\hline 5 & $6.88(1 \mathrm{H}, \mathrm{d}, 8.6)$ & $113.9(\mathrm{~d})$ & 3 \\
\hline 6 & $7.32(1 \mathrm{H}, \mathrm{d}, 8.6)$ & $128.5(\mathrm{~d})$ & 2 and 7 \\
\hline 7 & $4.62(1 \mathrm{H}, \mathrm{d}, 7.7)$ & $77.7(\mathrm{~d})$ & 8 and 9 \\
\hline 8 & $4.34(1 \mathrm{H}, \mathrm{dq}, 7.7,6.2)$ & $79.3(\mathrm{~d})$ & 9 \\
\hline 9 & $1.07(3 \mathrm{H}, \mathrm{d}, 6.2)$ & $15.7(\mathrm{q})$ & \\
\hline $1^{\prime}$ & - & $133.1(\mathrm{~s})$ & $3^{\prime}, 5^{\prime}$ and $7^{\prime}$ \\
\hline $2^{\prime}$ & $7.09(1 \mathrm{H}, \mathrm{d}, 8.4)$ & $129.7(\mathrm{~d})$ & $6^{\prime}$ and $7^{\prime}$ \\
\hline $3^{\prime}$ & $6.87(1 \mathrm{H}, \mathrm{d}, 8.4)$ & $116.4(\mathrm{~d})$ & \\
\hline $4^{\prime}$ & - & $156.1(\mathrm{~s})$ & $8,2^{\prime}$ and $6^{\prime}$ \\
\hline $5^{\prime}$ & $6.87(1 \mathrm{H}, \mathrm{d}, 8.4)$ & $116.4(\mathrm{~d})$ & \\
\hline $6^{\prime}$ & $7.09(1 \mathrm{H}, \mathrm{d}, 8.4)$ & $129.7(\mathrm{~d})$ & $2^{\prime}$ and $7^{\prime}$ \\
\hline $7^{\prime}$ & $3.32(2 \mathrm{H}, \mathrm{br} \mathrm{d}, 6.6)$ & $39.3(\mathrm{t})$ & \\
\hline $8^{\prime}$ & $5.93(1 \mathrm{H}, \mathrm{m})$ & $137.7(\mathrm{~d})$ & $7^{\prime}$ \\
\hline $9^{\prime}$ & $5.05(2 \mathrm{H}, \mathrm{dd}, 10.2,16.8)$ & $115.5(\mathrm{t})$ & $7^{\prime}$ \\
\hline MeO-4 & $3.79(3 \mathrm{H}, \mathrm{s})$ & $55.3(\mathrm{q})$ & - \\
\hline
\end{tabular}


Figure 3. $\mathrm{CD}$ of data compound 3.

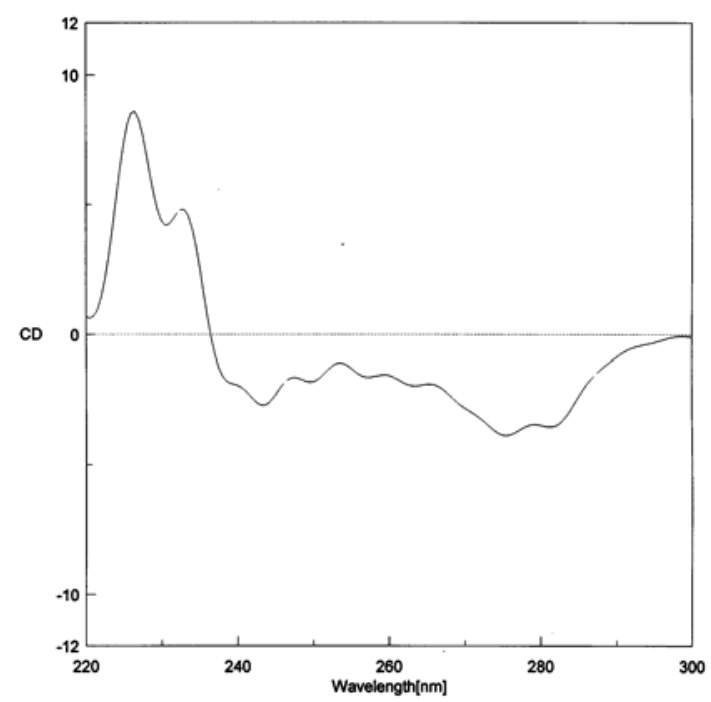

Compound $\mathbf{1 0}$ was obtained as a colorless amorphous powder. It has a molecular formula of $\mathrm{C}_{19} \mathrm{H}_{28} \mathrm{O}_{11}$, as indicated by the $[\mathrm{M}+\mathrm{Na}]^{+}$ion peak at $\mathrm{m} / \mathrm{z} 455.1619$ in the HRESITOFMS. The compound showed UV absorptions at 223 and $273 \mathrm{~nm}$, and IR bands at 3,366 (hydroxyl), 1,510 (conjugated unsaturation), and 1,071 and 1,043 (ether) $\mathrm{cm}^{-1}$. Compound 10 appeared to be a glycoside with tyrosol (4-hydroxyethylphenol) [31] as the aglycon, as suggested from the aromatic proton resonances at $\delta 7.10(2 \mathrm{H}, \mathrm{d}, J=8.6 \mathrm{~Hz}, \mathrm{H}-3$ and $\mathrm{H}-5)$ and $6.95(2 \mathrm{H}, \mathrm{d}, J=8.6 \mathrm{~Hz}, \mathrm{H}-2$ and $\mathrm{H}-6)$, and the aliphatic proton signals at $\delta 2.64(2 \mathrm{H}, \mathrm{t}, J=6.5 \mathrm{~Hz}, \mathrm{H}-7)$ and $3.54(2 \mathrm{H}, \mathrm{t}, J=6.5 \mathrm{~Hz}, \mathrm{H}-8)$ (Table 2). This was supported by the ${ }^{13} \mathrm{C}-\mathrm{NMR}$ signals at $\delta 155.7$ (C-1), 132.7 (C-4), 129.7 (C-3 and C-5), and 116.2 (C-2 and C-6), 38.2 (C-7) and 62.4 (C-8) [31].

Apart from the tyrosol moiety, compound $\mathbf{1 0}$ possessed two sugar units, as evidenced by two anomeric protons at $\delta 4.73\left(1 \mathrm{H}, \mathrm{d}, J=7.3 \mathrm{~Hz}, \mathrm{H}-1^{\prime}\right)$ and $4.17\left(1 \mathrm{H}, \mathrm{d}, J=7.6 \mathrm{~Hz}, \mathrm{H}-1^{\prime \prime}\right)$, which were correlated to the carbons at $\delta 100.7\left(\mathrm{C}-1^{\prime}\right)$ and $103.8\left(\mathrm{C}-1^{\prime \prime}\right)$, respectively, in the HMQC spectrum. The inner sugar was $\beta$-glucopyranose $\left[\delta_{\mathrm{H}} 4.73\left(1 \mathrm{H}, \mathrm{d}, J=7.3 \mathrm{~Hz}, \mathrm{H}-1^{\prime}\right), 3.22\left(2 \mathrm{H}, \mathrm{m}, \mathrm{H}-2^{\prime}\right.\right.$ and H-3'), 3.14 $\left(1 \mathrm{H}, \mathrm{t}, J=8.8 \mathrm{~Hz}, \mathrm{H}-4^{\prime}\right), 3.48\left(1 \mathrm{H}, \mathrm{dd}, J=8.8,6.6 \mathrm{~Hz}, \mathrm{H}-5^{\prime}\right), 3.55\left(1 \mathrm{H}, \mathrm{dd}, 10.9,6.6 \mathrm{~Hz}, \mathrm{H}-6^{\prime}{ }_{\mathrm{a}}\right)$ and $3.93\left(1 \mathrm{H}, \mathrm{dd}, 10.9,8.8 \mathrm{~Hz}, \mathrm{H}-6^{\prime}{ }_{\mathrm{b}}\right) ; \delta_{\mathrm{C}} \delta 100.7\left(\mathrm{C}-1^{\prime}\right), 73.2\left(\mathrm{C}-2^{\prime}\right), 76.5\left(\mathrm{C}-3^{\prime}\right), 69.6\left(\mathrm{C}-4^{\prime}\right), 75.8\left(\mathrm{C}-5^{\prime}\right)$ and $\left.68.2\left(\mathrm{C}-6^{\prime}\right)\right]$ [32], and its connection to the aglycon through an arylether bond was demonstrated by the HMBC correlation from H-1' to C-1 ( $\delta$ 155.7) and the NOESY interaction of H-1' with H-2(6). The other sugar unit was $\beta$-xylopyranose $\left[\delta_{\mathrm{H}} 4.17\left(1 \mathrm{H}, \mathrm{d}, J=7.6 \mathrm{~Hz}, \mathrm{H}-1^{\prime \prime}\right), 2.96(1 \mathrm{H}, \mathrm{dd}, J=8.7,7.6 \mathrm{~Hz}\right.$, H-2"), 3.06 (1H, t, $\left.J=8.7 \mathrm{~Hz}, \mathrm{H}-3^{\prime \prime}\right), 3.22$ (1H, m, H-4"), 3.65 (1H, dd, $\left.J=11.3,5.3 \mathrm{~Hz}, \mathrm{H}-5^{\prime \prime}{ }_{\mathrm{b}}\right), 2.94$ $\left.\left(1 \mathrm{H}, \mathrm{t}, J=11.3 \mathrm{~Hz}, \mathrm{H}-5^{\prime \prime}{ }_{\mathrm{a}}\right) ; \delta_{\mathrm{C}} \delta 103.8\left(\mathrm{C}-1^{\prime \prime}\right), 73.4\left(\mathrm{C}-2^{\prime \prime}\right), 76.5\left(\mathrm{C}-3^{\prime \prime}\right), 69.6\left(\mathrm{C}-44^{\prime \prime}\right), 65.6\left(\mathrm{C}-5^{\prime \prime}\right)\right]$, with its anomeric carbon linked to $\mathrm{C}-6^{\prime}$ of the glucose moiety through an ether bridge $[30,33]$. This linkage was further confirmed by the HMBC correlations between $\mathrm{C}-1^{\prime \prime}$ and $\mathrm{H}_{2}-6^{\prime}$, and between $\mathrm{C}-6^{\prime}$ and $\mathrm{H}-1^{\prime \prime}$.

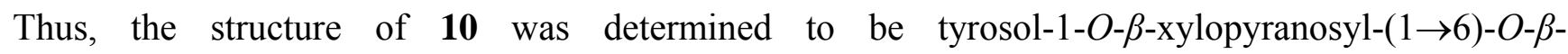
glucopyranoside. 
Table 2. ${ }^{1} \mathrm{H}-(500 \mathrm{MHz})$ and ${ }^{13} \mathrm{C}-\mathrm{NMR}(125 \mathrm{MHz})$ data of 10 (DMSO- $d_{6}, \delta$ in ppm and $J$ in $\mathrm{Hz}$ ) and $\mathrm{HMBC}$ correlations.

\begin{tabular}{|c|c|c|c|}
\hline Position & ${ }^{1} \mathbf{H}$ & ${ }^{13} \mathrm{C}$ & HMBC (correlation with ${ }^{1} \mathbf{H}$ ) \\
\hline 1 & - & $155.7(\mathrm{~s})$ & $2,3,5,6$ and $1^{\prime}$ \\
\hline 2 & $6.95(1 \mathrm{H}, \mathrm{d}, 8.6)$ & $116.2(d)$ & 3 and 6 \\
\hline 3 & $7.10(1 \mathrm{H}, \mathrm{d}, 8.6)$ & $129.7(d)$ & 2,5 and 7 \\
\hline 4 & - & $132.7(\mathrm{~s})$ & $2,6,7$ and 8 \\
\hline 5 & $7.10(1 \mathrm{H}, \mathrm{d}, 8.6)$ & $129.7(d)$ & 3,6 and 7 \\
\hline 6 & $6.95(1 \mathrm{H}, \mathrm{d}, 8.6)$ & $116.2(d)$ & 2 and 5 \\
\hline 7 & $2.64(2 \mathrm{H}, \mathrm{t}, 6.5)$ & $38.2(\mathrm{t})$ & 3,5 and 8 \\
\hline 8 & $3.54(2 \mathrm{H}, \mathrm{t}, 6.5)$ & $62.4(\mathrm{t})$ & 7 \\
\hline $1^{\prime}$ & $4.73(1 \mathrm{H}, \mathrm{d}, 7.3)$ & $100.7(d)$ & $5^{\prime}$ \\
\hline $2^{\prime}$ & $3.22(1 \mathrm{H}, \mathrm{m})$ & $73.2(d)$ & $3^{\prime}$ \\
\hline $3^{\prime}$ & $3.22(1 \mathrm{H}, \mathrm{m})$ & $76.5(\mathrm{~d})$ & $1^{\prime}$ \\
\hline $4^{\prime}$ & $3.14(1 \mathrm{H}, \mathrm{t}, 8.8)$ & $69.6(d)$ & $2^{\prime}, 3^{\prime}, 5^{\prime}$ and $6_{\mathrm{b}}^{\prime}$ \\
\hline $5^{\prime}$ & $3.48(1 \mathrm{H}, \mathrm{dd}, 8.8,6.6)$ & $75.8(d)$ & $1^{\prime}$ and $6_{\mathrm{a}}^{\prime}$ \\
\hline $6_{a}^{\prime}$ & $3.55(1 \mathrm{H}, \mathrm{dd}, 10.9,6.6)$ & $68.2(\mathrm{t})$ & - \\
\hline $6_{b}^{\prime}$ & $3.93(1 \mathrm{H}, \mathrm{dd}, 10.9,8.8)$ & - & $5^{\prime}$ and $1^{\prime \prime}$ \\
\hline $1^{\prime \prime}$ & $4.17(1 \mathrm{H}, \mathrm{d}, 7.6)$ & $103.8(d)$ & $5^{\prime \prime}{ }_{\mathrm{a}}$ and $5^{\prime \prime}, 6_{\mathrm{a}}^{\prime}, 6^{\prime}{ }_{\mathrm{b}}$ \\
\hline $2^{\prime \prime}$ & $2.96(1 \mathrm{H}, \mathrm{dd}, 8.7,7.6)$ & $73.4(d)$ & $1 "$ and $3 "$ \\
\hline $3^{\prime \prime}$ & $3.06(1 \mathrm{H}, \mathrm{t}, 8.7)$ & $76.5(d)$ & $2 ", 5^{\prime \prime}$ and $5_{b}^{\prime \prime}$ \\
\hline $4 "$ & $3.22(1 \mathrm{H}, \mathrm{m})$ & $69.6(d)$ & $2 ", 3 ", 5^{\prime \prime}$ and $5^{\prime \prime}$ \\
\hline $5{ }_{a}^{\prime \prime}$ & $2.94(1 \mathrm{H}, \mathrm{t}, 11.3)$ & $65.6(\mathrm{t})$ & - \\
\hline $5_{\mathrm{b}}^{\prime \prime}$ & $3.65(1 \mathrm{H}, \mathrm{dd}, 11.3,5.3)$ & - & $1^{\prime \prime}$ \\
\hline
\end{tabular}

It should be noted that although neolignans are frequently identified from the Annonaceae, they were not previously found in the genus Miliusa, and this is the first time that neolignans were isolated from a plant of this genus.

\section{Experimental}

\subsection{General}

Optical rotations were measured on a Perkin-Elmer 341 polarimeter, and the CD spectra were recorded on a JASCO J-715 spectropolarimeter. UV spectra were obtained on a Shimadzu UV-160A UV/vis spectrometer and IR spectra on a Perkin-Elmer FT-IR 1760X spectrophotometer. Mass spectra were recorded on a Micromass LCT mass spectrometer or a Thermo-Finnigan Polaris Q mass spectrometer. NMR spectra were obtained with a Bruker Avance DPX-300 FT-NMR spectrometer (300 MHz) or a JEOL JMN-A $500 \mathrm{NMR}$ spectrometer (500 MHz). Vacuum-liquid column 
chromatography (VLC), column chromatography (CC) and medium pressure liquid chromatography (MPLC) were performed with silica gel 60 (Merck, Kieselgel 60, 70-230 mesh), silica gel 60 (Merck, Kieselgel 60, 230-400 mesh), Diaion HP20SS (Mitsubishi Chemical Co.) and Sephadex LH-20 (25-100 $\mu \mathrm{m}$, Pharmacia Fine Chemical Co. Ltd.). Preparative TLC was carried out with silica gel plate (Merck, Kieselgel 60 F254).

\subsection{Plant Material}

The twigs of Miliusa mollis Pierre were collected in Bangkok, Thailand by one of us (T.C.) and identified by R. W. J. M. van der Ham, as previously described [1].

\subsection{Extraction and Isolation}

The dried and powdered plant material $(380 \mathrm{~g})$ was extracted with $\mathrm{MeOH}(3 \times 3 \mathrm{~L})$ to give $24 \mathrm{~g}$ of an extract, which was then subjected to VLC on silica gel using solvent mixtures of increasing polarity ( $n$-hexane, $\mathrm{CH}_{2} \mathrm{Cl}_{2}$, EtOAc and $\mathrm{MeOH}$ ) to give eight fractions (A-H).

Fraction D (98 mg) was further separated by $\mathrm{CC}$ on silica gel $(15.4 \mathrm{~g})$ with gradient elution $(n-$ hexane- $\mathrm{CH}_{2} \mathrm{Cl}_{2}$ ) to give seven fractions (D1-D7). Fraction D4 (33 mg) was purified on Sephadex LH$20\left(\mathrm{CH}_{2} \mathrm{Cl}_{2}-\mathrm{MeOH} 1: 1\right)$ to give 1 (22 mg).

Fraction E (321 mg) was separated by $\mathrm{CC}$ on silica gel $(21.62 \mathrm{~g})$ with $n$-hexane- $\mathrm{CH}_{2} \mathrm{Cl}_{2}$ gradient elution to give ten fractions (E1-E10). Fraction E6 (184 mg) was separated on Sephadex LH-20 $\left(\mathrm{CH}_{2} \mathrm{Cl}_{2}-\mathrm{MeOH} 1: 1\right)$ to give 2 (100 mg).

Fraction F (1.9 g) was separated by MPLC (silica gel, $n$-hexane- $\mathrm{CH}_{2} \mathrm{Cl}_{2}$ gradient elution) to give eleven fractions (F1-F11). Fraction F7 (171.9 mg) was separated with Sephadex-LH-20/ $\mathrm{CH}_{2} \mathrm{Cl}_{2}$ $\mathrm{MeOH}(1: 1)$ to give six fractions (F7-1 to F7-6). Fraction F7-4 (7 mg) was purified by preparative TLC (silica gel, $n$-hexane-EtOAc-acetone 90:8:2) to yield $2 \mathrm{mg}$ of 3. Fraction F8 (379 mg) was separated with Sephadex $\mathrm{LH}-20 / \mathrm{CH}_{2} \mathrm{Cl}_{2}-\mathrm{MeOH}$ (1:1) to give 4 (339.0 mg).

Fraction G (1.6 g) was separated by MPLC (silica gel, $n$-hexane-EtOAc gradient elution) to give twelve fractions (G1-G12). Fraction G9 (433.4 mg) was separated on Sephadex LH-20 (acetone) to give 5 (163 mg).

Fraction $\mathrm{H}(16.5 \mathrm{~g})$ was fractionated on Diaion HP20SS, eluted with $\mathrm{H}_{2} \mathrm{O}-\mathrm{MeOH}(100: 0-0: 100)$ to give seven fractions $(\mathrm{H} 1-\mathrm{H} 7)$. Fraction H7 (405.9 mg) was separated on silica gel $(21.0 \mathrm{~g})$ with EtOAc-MeOH- $\mathrm{H}_{2} \mathrm{O}$ gradient elution to give fourteen fractions (H7-1 to H7-14). Fraction H7-2 (25 mg) was further purified with Sephadex- $\mathrm{LH}-20 / \mathrm{CH}_{2} \mathrm{Cl}_{2}-\mathrm{MeOH}(1: 1)$ to give 6 (2 mg). Fraction H7-6 (52 mg) was separated on Sephadex LH-20, eluted with $\mathrm{CH}_{2} \mathrm{Cl}_{2}-\mathrm{MeOH}$ (1:1) to give four fractions (H7-6-1 to H7-6-4). Fraction H7-6-4 (10 mg) was further purified by $\mathrm{CC}$ (silica gel, $\mathrm{CH}_{2} \mathrm{Cl}_{2}$-acetone 1:4) to give 7 (2 mg). Fraction H7-7 (38 mg) was separated with Sephadex LH-20/ $\mathrm{CH}_{2} \mathrm{Cl}_{2}-\mathrm{MeOH}$ (1:1) to give four fractions (H7-7-1 to H7-7-4). Fraction H7-7-4 (15 mg) was further purified by CC on silica gel, eluted with $\mathrm{CH}_{2} \mathrm{Cl}_{2}$-acetone (1:4) to give $2 \mathrm{mg}$ of 7 and $5 \mathrm{mg}$ of $\mathbf{8}$. Fraction $\mathrm{H} 4$ (282 $\mathrm{mg}$ ) was separated by $\mathrm{CC}$ on silica gel (19.6 g) with EtOAC-MeOH- $\mathrm{H}_{2} \mathrm{O}$ gradient elution to give twelve fractions (H4-1 to H4-12). Fraction H4-3 (16 mg) was separated on Sephaddex LH-20(MeOH) to give three fractions (H4-3-1 to H4-3-3). Fraction H4-3-1 (14 mg) was further purified by preparative TLC (silica gel) with EtOAc-MeOH-H $\mathrm{H}_{2} \mathrm{O}(92: 6: 2)$ to yield $10 \mathrm{mg}$ of 9. Fraction H4-6 (39 mg) was separated 
on Sephadex LH-20 (MeOH) to give six fractions (H4-6-1 to H4-6-6). Fraction H4-6-4 (26 mg) was further purified by $\mathrm{CC}$ (silica gel, EtOAc- $\mathrm{MeOH}-\mathrm{H}_{2} \mathrm{O}$ 80:12:8) to give $\mathbf{1 0}(3 \mathrm{mg}$ ).

(2S,3S)-2,3-Dihydro-2-(4-methoxyphenyl)-3-methyl-5-[1(E)-propenyl]benzofuran (1): colorless oil; $[\alpha]_{D}^{20}-13.22$ (c 0.42, MeOH); CD (MeOH, c 0.001): $[\theta]_{300}-401,[\theta]_{264}-2,296,[\theta] 226+1,791$; EI-MS $m / z 281[\mathrm{M}+1]^{+}, 280[\mathrm{M}]^{+}, 265,251,157,148,135,131,115,103,91$; HRESITOFMS $m / z 303.1280$ $[\mathrm{M}+\mathrm{Na}]^{+}$(calcd. for $\left.\mathrm{C}_{19} \mathrm{H}_{20} \mathrm{O}_{2} \mathrm{Na}, 303.1361\right)$; UV $\lambda_{\max }(\mathrm{MeOH}) \mathrm{nm}(\log \varepsilon) 228$ (3.76), 274 (3.26); IR $v_{\max }$ (film): $1515,1486,1243 \mathrm{~cm}^{-1} ;{ }^{1} \mathrm{H}-\mathrm{NMR}\left(300 \mathrm{MHz}, \mathrm{CDCl}_{3}\right): \delta 7.35\left(2 \mathrm{H}, \mathrm{d}, J=8.7 \mathrm{~Hz}, \mathrm{H}-2^{\prime}\right.$, H-6'), 7.14 (1H, br s, H-4), $7.12(1 \mathrm{H}, \mathrm{d}, J=8.1 \mathrm{~Hz}, \mathrm{H}-6), 6.91$ (2H, d, $\left.J=8.7 \mathrm{~Hz}, \mathrm{H}-3^{\prime}, \mathrm{H}-5^{\prime}\right), 6.76$ $(1 \mathrm{H}, \mathrm{d}, J=8.1 \mathrm{~Hz}, \mathrm{H}-7), 6.37(1 \mathrm{H}, \mathrm{d}, J=15.8 \mathrm{~Hz}, \mathrm{H}-8), 6.09(1 \mathrm{H}, \mathrm{dq}, J=15.8,6.3 \mathrm{~Hz}, \mathrm{H}-9), 5.09$ $(1 \mathrm{H}, \mathrm{d}, J=9.0 \mathrm{~Hz}, \mathrm{H}-2), 3.81(3 \mathrm{H}, \mathrm{s}, \mathrm{MeO}), 3.39(1 \mathrm{H}, \mathrm{m}, \mathrm{H}-3), 1.86(3 \mathrm{H}, \mathrm{d}, J=6.3 \mathrm{~Hz}, \mathrm{Me}-10), 1.39$ $(3 \mathrm{H}, \mathrm{d}, J=6.6 \mathrm{~Hz}, \mathrm{Me}-3) ;{ }^{13} \mathrm{C}-\mathrm{NMR}\left(75 \mathrm{MHz}, \mathrm{CDCl}_{3}\right): \delta 159.6$ (C-7a), $158.3\left(\mathrm{C}-4{ }^{\prime}\right), 132.7$ (C-3a), 132.4 (C-1'), 131.2 (C-5), 130.8 (C-8), 127.6 (C-2', C-6'), 126.3 (C-6), 122.9 (C-9), 120.7 (C-4), 114.0 (C-3',C-5'), 109.2 (C-7), 92.6 (C-2), 45.2 (C-3), 55.3 (MeO), 18.3 (C-10), 17.8 (Me-3).

(7S,8S)-threo- $\Delta^{8^{\prime}}$-4-methoxyneolignan (3): colorless oil; $[\alpha]_{D}^{20}+10.0$ (c 0.05, MeOH); CD (MeOH, c 0.002): $[\theta]_{276}-1,932,[\theta]_{233}+2,392$; EI-MS $m / z 298[\mathrm{M}]^{+}, 281,162,161,137,133,121,115,105,91$, 77; HRESITOFMS $m / z 321.1375[\mathrm{M}+\mathrm{Na}]^{+}$(calcd. for $\mathrm{C}_{19} \mathrm{H}_{22} \mathrm{O}_{3} \mathrm{Na}, 321.1468$ ); UV $\lambda_{\max }(\mathrm{MeOH}) \mathrm{nm}$ (log ع) 227 (4.18), 275 (3.48); IR $v_{\max }$ (film): 3448 (br), 1509, $1243 \mathrm{~cm}^{-1}$; ${ }^{1} \mathrm{H}-\mathrm{NMR}\left(300 \mathrm{MHz}, \mathrm{CDCl}_{3}\right.$ ) and ${ }^{13} \mathrm{C}$-NMR $\left(75 \mathrm{MHz}, \mathrm{CDCl}_{3}\right)$ : see Table 1 .

Tyrosol-1-O- $\beta$-xylopyranosyl- $(1 \rightarrow 6)$-O- $\beta$-glucopyranoside $(\mathbf{1 0})$ : colorless amorphous powder; $[\alpha]_{D}^{20}$ -48.75 (c 0.08, MeOH); EI-MS $m / z$ 414, 207, 167, 149, 138, 107, 77; HRESITOFMS $m / z 455.1619$ $[\mathrm{M}+\mathrm{Na}]^{+}$(calcd. for $\left.\mathrm{C}_{19} \mathrm{H}_{28} \mathrm{O}_{11} \mathrm{Na}, 455.1529\right)$; UV $\lambda_{\max }(\mathrm{MeOH}) \mathrm{nm}(\log \varepsilon) 223$ (3.51), 273 (2.77); IR $v_{\max }$ (film): 3366 (br), 1510, 1071, $1043 \mathrm{~cm}^{-1}$; ${ }^{1} \mathrm{H}-\mathrm{NMR}\left(500 \mathrm{MHz}, \mathrm{DMSO}-d_{6}\right)$ and ${ }^{13} \mathrm{C}-\mathrm{NMR}(125$ MHz, DMSO- $\left.d_{6}\right)$ : see Table 2.

\section{Conclusion}

Three new compounds including (2S,3S)-2,3-dihydro-2-(4-methoxyphenyl)-3-methyl-5-[1(E)propenyl]benzofuran, $(7 S, 8 S)$ - threo- $\Delta^{8^{\prime}}-4$-methoxyneolignan and tyrosol-1- $O$ - $\beta$-xylopyranosyl- $(1 \rightarrow 6)$ $O-\beta$-glucopyranoside were isolated from the twigs of Miliusa mollis Pierre. The presence of neolignans in the genus Miliusa was reported for the first time in this study.

\section{Acknowledgements}

K.S. acknowledges the financial support from The Thailand Research Fund through the Royal Golden Jubilee Ph.D. Program (PHD/0261/2549). She is also a recipient of Chulalongkorn University Graduate Scholarship in Commemoration of HM King Bhumibol Adulyadej's $72^{\text {nd }}$ Anniversary. 


\section{References}

1. Chaowasku, T.; Mols, J.; van der Ham, R.W.J.M. Pollen morphology of Miliusa and relatives (Annonaceae). Grana 2008, 47, 175-184.

2. Harrigan, G.G.; Gunatilaka, A.A.L.; Kingston, D.G.I.; Chan, G.W.; Johnson, R.K. Isolation of bioactive and other oxoaporphine alkaloids from two annonaceous plants, Xylopia aethiopica and Miliusa cf. banacea. J. Nat. Prod. 1994, 57, 68-73.

3. Jumana, S.; Hasan, C.M.; Rashid, M.A. Alakaloids from the stem bark of Miliusa velutina. Biochem. Syst. Ecol. 2000, 28, 483-485.

4. Wu, R.; Ye, Q.; Chen, N.Y.; Zhang, G.L. A new norditerpene from Miliusa balansae Finet et Gagnep. Chin Chem Lett 2001, 12, 247-248.

5. Kamperdick, C.; Hong Van, N.; Van Sung, T. Constituents from Miliusa balansae (Annonaceae). Phytochemistry 2002, 61, 991-994.

6. Chen, B.; Feng, C.; Li, B.G.; Zhang, G.L. Two new alkaloids from Miliusa cuneata. Nat. Prod. Res. 2003, 17, 397-402.

7. Huong, D.T.; Kamperdick, C.; Van Sung, T. Homogentisic acid derivatives from Miliusa balansae. J. Nat. Prod. 2004, 67, 445-447.

8. Brophy, J.J.; Goldsack, R.J.; Forster, P.I. The leaf oils of the Australian species of Miliusa (Annonaceae). J. Essent. Oil Res. 2004, 16, 253-255.

9. Huong, D.T.; Luong, D.V.; Thao, T.T.P.; Sung, T.V. A new flavone and cytotoxic activity of flavonoid constituents isolated from Miliusa balansae (Annonaceae). Pharmazie 2005, 60, $627-629$.

10. Zhang, H.J.; Ma, C.Y.; Van Hung, N.; Cuong, N.M.; Tan, G.T.; Santarsiero, B.D.; Mesecar, A.D.; Soejarto, D.D.; Pezzuto, J.M.; Fong, H.H.S. Miliusanes, a class of cytotoxic agents from Miliusa sinensis. J. Med. Chem. 2006, 49, 693-708.

11. Lei, Y.; Wu, L.J.; Shi, H.M.; Tu, P.F. Three new glycosides from the stems of Miliusa balansae. Helv. Chim. Acta 2008, 91, 495-500.

12. Huong, D.T.; Van, N.T.H.; Kamperdick, C.; Anh, N.T.H.; Sung, T.V. Two new bis-styryl compounds from Miliusa balansae. Z. Naturforsch. B. 2008, 63, 335-338.

13. Smitinand, T. Thai Plant Names, revised Ed.; Prachachon Co. Ltd.: Bangkok, Thailand, 2001; p 359.

14. Achenbach, H.; Grob, J.; Domínguez, X.A.; Cano, G.; Star, J.V.; Brussolo, L.D.C.; Munoz, G.; Salgado, F.; LÓpez, L. Lignans, neolignans and norneolignans from Krameria cystisoides. Phytochemistry 1987, 26, 1159-1166.

15. Chauret, D.C.; Bernard, C.B.; Arnason, J.T.; Durst, T.; Krishnamurty, H.G.; SanchezVindas, P.; Moreno, N.; San Roman, L.; Poveda, L. Insecticidal neolignans from Piper decurrens. J. Nat. Prod. 1996, 59, 152-155.

16. Achenbach, H.; Utz, W.; Lozano, B.; Touché, E.M.G.; Moreno, S. Lignans and neolignans from Krameria parvifolia. Phytochemistry 1996, 43, 1093-1095.

17. Shahat, A.A. Procyanidins from Adansonia digitata. Pharm. Biol. 2006, 44, 445-450.

18. Foo, L.Y.; Newman, R.; Waghorn, G.; McNabb, W.C.; Ulyatt, M.J. Proanthocyanidins from Lotus corniculatus. Phytochemistry 1996, 41, 617-624. 
19. Pang, S.Q.; Wang, G.Q.; Huang, B.K.; Zhang, Q.Y.; Qin, L.P. Isoquinoline alkaloids from Broussonetia papyrifera fruits. Chem. Nat. Compd. 2007, 43, 100-102.

20. Zhang, Z.Z.; ElSohly, H.N.; Jacob, M.R.; Pasco, D.S.; Walker, L.A.; Clark, A.M. New sesquiterpenoids from the root of Guatteria multivenia. J. Nat. Prod. 2002, 65, 856-859.

21. Fischer, D.C.H.; Gonçalves, M.I.; Oliveira, F.; Alvarenga, M.A. Constituents from Siparuna apiosyce. Fitoterapia 1999, 70, 322-323.

22. Zanin, S.M.W.; Lordello, A.L.L. Alcalóides aporfinóides do gênero Ocotea (Lauraceae). Quim. Nova 2007, 30, 92-98.

23. Lo, W.L.; Wu, Y.C.; Hsieh, T.J.; Kuo, S.H.; Lin, H.C.; Chen, C.Y. Chemical constituents from the stems of Michelia compressa. Chin. Pharm. J. 2004, 56, 69-75.

24. Miyase, T.; Ueno, A.; Takizawa, N.; Kobayashi, H.; Oguchi, H. Ionone and lignan glycosides from Epimedium diphyllum. Phytochemistry 1989, 28, 3483-3485.

25. Snider, B.B.; Han, L.N.; Xie, C.Y. Synthesis of 2,3-dihydrobenzofurans by $\mathrm{Mn}(\mathrm{OAc})_{3}$-based oxidative cycloaddition of 2-cyclohexenones with alkenes. Synthesis of ( \pm -conocarpan. J. Org. Chem. 1997, 62, 6978-6984.

26. Achenbach, H.; Utz, W.; Usubillaga, A.; Rodriguez, H.A. Lignans from Krameria ixina. Phytochemistry 1991, 30, 3753-3757.

27. Achenbach, H.; Utz, W.; Sánchez, H.; Touché, E.M.G.; Verde, J.; Dominguez, X.A. Neolignans, nor-neolignans and other compounds from roots of Krameria grayi. Phytochemistry 1995, 39, 413-415.

28. Braga, A.C.H.; Zacchino, S.; Badano, H.; Sierra, M.G.; Rúveda, E.A. ${ }^{13}$ C NMR spectral and conformational analysis of 8-O-4' neolignans. Phytochemistry 1984, 23, 2025-2028.

29. Morais, S.K.R.; Teixeira, A.F.; Torres, Z.E.D.S.; Nunomura, S.M.; Yamashiro-Kanashiro, E.H.; Lindoso, J.A.L.; Yoshida, M. Biological activities of lignoids from amazon Myristicaceae species: Virola michelii, V. mollissima, V. pavonis and Iryanthera juruensis. J. Brazil. Chem. Soc. 2009, 20, 1110-1118.

30. Huo, C.H.; Liang, H.; Zhao, Y.Y.; Wang, B.; Zhang, Q.Y. Neolignan glycosides from Symplocos caudata. Phytochemistry 2008, 69, 788-795.

31. Sommart, U.; Rukachaisirikul, V.; Sukpondma, Y.; Phongpaichit, S.; Towatana, N.H.; Graidist, P.; Hajiwangoh, Z.; Sakayaroj, J.A. Cyclohexenone derivative from Diaporthaceous fungus PSUH2. Arch. Pharm. Res. 2009, 32, 1227-1231.

32. Agrawal, P.K. NMR spectroscopy in the structural elucidation of oligosaccharides and glycosides. Phytochemistry 1992, 31, 3307-3330.

33. Schroeder, C.; Lutterbach, R.; Stöckigt, J. Preparative biosynthesis of natural glucosides and fluorogenic substrates for $\beta$-glucosidases followed by in vivo ${ }^{13} \mathrm{C}$ NMR with high density plant cell cultures. Tetrahedron 1996, 52, 925-934.

Sample Availability: Samples of the compounds are available from the authors.

(C) 2010 by the authors; licensee Molecular Diversity Preservation International, Basel, Switzerland. This article is an open-access article distributed under the terms and conditions of the Creative Commons Attribution license (http://creativecommons.org/licenses/by/3.0/). 